\title{
INAKTIVITAS FISIK, HYPERTRIGLYCERIDEMIC-WAIST (HTW) PHENOTYPE SEBAGAI FAKTOR RISIKO PENINGKATAN KADAR C-REACTIVE PROTEIN PADA REMAJA SINDROM METABOLIK
}

\author{
Desy Prima Lestari, Muhammad Sulchan*) \\ Program Studi Ilmu Gizi Fakultas Kedokteran Universitas Diponegoro \\ Jl.Dr.Sutomo No.18, Semarang, Telp (024) 8453708, Email : gizifk@undip.ac.id
}

\begin{abstract}
Background: The prevalance of obesity adolescent in Indonesia was increased from 1,4\% to 1,6\% on $2010-2013$. Obesity is associated with metabolic syndrome (MetS), inflammation and increase risk of degenerative diseases such as type 2 diabetes melitus and heart diseases. Physical activity has a linked to obesity and MetS. Low Physical activity can increase waist circumference and triglyserides (hypertryliceridemic-waist phenotype) which is related to elevated C-Reactive Protein (CRP) levels.

Method: A total 835 boys and girl between 15-18 years were participated in this study. This was a cross-sectional study with a random sample of 38 adolescents of both genders from public school in Semarang. The data were colected in Mei 2014. The participants were assessed anthropometric measurements (weight, height, and waist circumference) and level of triglyceride (TG), high-density-lipoprotein-cholestrol (HDL-c), fasting glucose and CRP were measured. NCEP-ATP III was used to determined metabolic syndrome. The HTW was defined as serum triglyceride concentration $\geq 100 \mathrm{mg} / \mathrm{dL}$ and concurent waist circumference $\geq 90^{\text {th }}$ percentile for gender and ages. Physical activity data collected by Quantification de L'Activite Physique en Altidue ches les Enfants (QAPACE). Physical inactivity and HTW were concidered as risk factor for elevated CRP.

Result: The prevalance of obesity was 7,9\% and metabolic syndrome was 15,2\%. Low physical activity were increased risk of elevated CRP $(R P: 1,12)$. Elevated waist circumference and triglycerides level were at increased risk of metabolic syndrome (RP: 3,85) but not risk factor for elevated CRP (RP: 0,45).

Conclusion: The prevalance of obesity in SMAN2 Semarang higher than prevalence of obesity prevalance in Riskesdas 2013. The metabolic syndrome have been identified in obesity adolescent. Physical inactivity increased risk of elevated CRP and Hypertriglyceridemic-waist Phenotype is a risk factor of Metabolic Syndrome.

Keyword: Metabolic Syndrome, Physical Activity, Hypertriglyceridemic-Waist Phenotype, C-reactive Protein
\end{abstract}

\begin{abstract}
ABSTRAK
Latar Belakang: Prevalensi obesitas di Indonesia dari tahun 2010 hingga 2013 mengalami peningkatan dari 1,4\% menjadi 1,6\%. Obesitas memiliki hubungan dengan kejadian sindrom metabolik, inflamasi dan penyakit degenartif seperti penyakit jantung dan diabetes melitus tipe 2. Aktivitas fisik memiliki hubungan dengan obesitas dan sindrom metabolik. Aktivitas fisik yang rendah dapat menyebabkan kenaikan lingkar pinggang dan trigliserida yang juga berhubungan dengan status pro-inflamatori seperti C-Reactive Protein (CRP)

Metode: Desain penelitian ini adalah cross-sectional yang melibatkan 835 siswa laki-laki dan perempuan yang berusia 15-18 tahun. Dengan teknik pengambilan sampel secara random didapatkan sampel sejumlah 38 orang. Pengukuran yang dilakukan terhadap responden adalah pengukuran antropometri, pemeriksaan kadar trigliserida. High Density Lipoprotein Cholestrol (HDL-c), gula darah puasa (GDP) dan CRP. Kategori penentuan sindrom metabolik berdasarkan kriteria NCEP-ATP III. Kategori HTW adalah peningkatan serum trigliserida $\geq 100 \mathrm{mg} / \mathrm{dL}$ dan lingkar pinggang $\geq$ persentil 90. Data aktivitas fisik didapatkan melalui kuisioner Quantification de L'Activite Physique en Altidue ches les Enfants (QAPACE) Inaktivitas fisik dan HTW akan ditelusuri nilai faktor resikonya terhadap peningkatan kadar CRP.

Hasil: Prevalensi obesitas 7,9\% dan prevalensi sindrom metabolik sebesar 15,2\%. Aktivitas fisik merupakan faktor risiko peningkatan CRP $(1,12)$. Peningkatan kadar trigliserida dan lingkar pinggang meningkatkan resiko sindrom metabolik (RP: 3,85) namun tidak terbukti sebagai faktor risiko terhadap peningkatan CRP.

Simpulan: Prevalensi obesitas di SMAN2 semarang lebih tinggi dibandingkan Riskesdas 2013. Telah terjadi sindrom metabolik pada remaja obesitas. Inaktivitas fisik merupakan faktor risiko peningkatan CRP dan HTW merupakan faktor resiko terjadinya Sindrom metabolik.
\end{abstract}

Kata kunci: Sindrom Metabolik, Aktivitas Fisik, Hypertriglyceridemic-Waist Phenotype, C-Reactive Protein

\section{PENDAHULUAN}

Angka prevalensi obesitas remaja dari tahun 2010 hingga 2013 mengalami peningkatan, yaitu dari $1,4 \%$ menjadi $1,6 \%{ }^{1,2}$ Obesitas yang terjadi ketika remaja akan memperbesar risiko terjadinya kormobiditas obesitas, sindrom metabolik dan penyakit degeneratif ketika dewasa. $^{3,4}$ Prevalensi sindrom metabolik telah

\footnotetext{
${ }^{*}$ Penulis Penanggungjawab
} 
melewati angka 30\% berdasarkan data penelitian di Semarang. ${ }^{5}$ Salah satu faktor pencetus obesitas adalah gaya hidup sedenter dan kurang aktivitas fisik. ${ }^{6}$ Gaya hidup sedenter yang dapat memicu obesitas meliputi kebiasaan menonton tv, bermain video game, bermain komputer, penggunaan internet, dan penggunaan kendaraan bermotor dalam jarak dekat. ${ }^{7,8}$ Kurangnya olahraga juga dapat menyebabkan obesitas dan berpengaruh terhadap sensitivitas insulin, profil glukosa darah, profil lipid dan tekanan darah. Selain itu juga dapat berisiko meningkatkan status pro-inflammatory ${ }^{9,10}$

Mengetahui status obesitas sejak dini sangat penting dalam upaya pencegahan dampak buruk obesitas dikemudian hari. Salah satu cara untuk menentukan status obesitas sekaligus menggambarkan sebaran lemak tubuh, yaitu dengan melakukan pengukuran lingkar pinggang. Kenaikan lingkar pinggang merupakan cara yang mudah dan murah untuk pemeriksaan terjadinya obesitas sentral akan tetapi etiologi sindrom metabolik tidak dapat ditegakkan dengan hanya satu atau dua kriteria. Terdapat kriteria lain dalam penentuan sindrom metabolik, yaitu kejadian hipertensi, hipokolestrol dan resisten insulin. ${ }^{1112}$

Kenaikan lingkar pinggang $\geq$ persentil 90 dan kadar trigliserida $\geq 100 \mathrm{mg} / \mathrm{dL}$ disebut juga dengan Hypertrigliserida-Waist Phenotype (HTW $).{ }^{13}$ HTW memiliki asosiasi terhadap kejadian sindrom metabolik pada remaja. Salah satu penelitian mengemukakan bahwa HTW berkaitan dengan tingginya nilai kolesterol total, kolesterol LDL, dan rendahnya kolesterol HDL. ${ }^{14}$ Selain itu, HTW juga dapat meningkatkan risiko terjadinya intoleransi glukosa dan hiperinsulinemia. Salah satu cara untuk mengetahui keterkaitan HTW dengan sindrom metabolik adalah melalui pemeriksaan biomarker pro-inflammatory. ${ }^{15}$

Pemeriksaan biomarker pro-inflammatory yang dapat dilakukan adalah melalui pemeriksaan C-Reactive Protein (CRP). ${ }^{16}$ Salah satu penelitian di Amerika Serikat menemukan kadar CRP yang tinggi pada remaja dengan sindrom metabolik. ${ }^{17}$ Dengan melakukan penelitian terhadap kenaikan kadar CRP dapat memperjelas hubungan HTW sebagai prediktor awal sindrom metabolik. ${ }^{18}$

Berdasarkan hal tersebut peneliti tertarik untuk melakukan untuk meneliti aktivitas fisik, HTW terhadap kadar CRP.

\section{METODE}

Populasi dalam penelitian ini adalah siswa berusia 15-18 tahun di SMA Negeri 2 Semarang dengan desain cross sectional. Sampel yang mengikuti penelitian ini sesuai dengan kriteria inklusi yaitu subyek obesitas dengan Indeks Massa Tubuh terhadap umur (IMT/U) $\geq$ persentil 95, kemudian sampel dengan obesitas sentral dengan lingkar pinggang di atas persentil 90 (laki-laki $\geq 94$ $\mathrm{cm}$, perempuan $\geq 87 \mathrm{~cm}$ ). Pada penelitian ini kriteria ekslusi yang ditetapkan adalah subyek mengundurkan diri, sakit, atau meninggal dunia saat penelitian berlangsung.

Variabel terikat dalam penelitian ini adalah kadar CRP, sedangkan variabel bebas adalah aktivitas fisik dan kejadian HTW. Skrining, pemilihan subyek penelitian, pengambilan sampel darah, dan penyebaran kuisioner aktivitas fisik dilakukan pada bulan Mei 2014. Setiap subyek terpilih diberikan informed consent sebagai tanda persetujuan menjadi subyek penelitian.

Penentuan status sindrom metabolik berdasarkan kriteria National Cholesterol Education Program Adult Treatment Panel (NCEP-ATP) III yaitu, Obesitas sentral (lingkar pinggang $\geq$ persentil ke-90, yaitu $\geq 93 \mathrm{~cm}$ untuk laki-laki, $\geq 87 \mathrm{~cm}$ untuk perempuan), hipertensi (tekanan darah sistolik dan/atau diastolik $\geq$ persentil ke-90, yaitu tekanan darah sistolik $\geq 122$ $\mathrm{mmHg}$ dan/atau tekanan darah diastolik $\geq 77$ $\mathrm{mmHg}$ ), kadar GDP $\geq 110 \mathrm{mg} / \mathrm{dL}$, kadar trigliserida $\geq 110 \mathrm{mg} / \mathrm{dL}$, dan kadar kolesterol HDL $<40$ $\mathrm{mg} / \mathrm{dL}$, sedangkan subyek termasuk pra sindrom metabolik jika memenuhi 1-2 faktor risiko sindrom metabolik. Terdapat 47 orang yang menjalani pemeriksaan status sindrom metabolik.

Pengukuran berat badan diukur menggunakan timbangan berat badan dengan ketelitian $0,1 \mathrm{~kg}$. Tinggi badan diukur menggunakan microtoise dengan ketelitian $0,1 \mathrm{~cm}$. Apabila ditemukan responden yang memiliki status gizi obesitas berdasarkan persentil, maka responden tersebut akan menjalani prosedur pengukuran lingkar pinggang diukur menggunakan pita ukur/metlin dengan ukuran maksimal $150 \mathrm{~cm}$. Pengukuran tekanan darah menggunakan Sphygmomanometer air raksa, metode tidak langsung dengan cara auskultasi. Pengukuran trigliserida, HDL dan Gula Darah Puasa (GDP) menggunakan metode enzymatic colorimetric pada subyek yang telah berpuasa selama 8-12 jam. Pengambilan data lebih lanjut dilakukan terhadap 38 orang. Pengambilan data aktivitas fisik diperoleh melalui formulir kuisioner Quantification de L'Activite Physique en Altidue ches les Enfants (QAPACE) lalu dihitung nilai Metabolic Equivalent (MET). Aktivitas fisik dikatakan rendah jika $\leq 600$ METs/minggu, sedang jika $\geq 600-2999$ METs/minggu dan tinggi jika $\geq$ 
3000 METs/minggu. Pengkategorian HTW berdasarkan lingkar pinggang $\geq 90 \mathrm{~cm}$ dan kadar trigliserida $\geq 100 \mathrm{mg} / \mathrm{dL}$. Kadar CRP diukur menggunakan metode aglutinasi. Kadar CRP dikatakan normal apabila $\leq 6 \mathrm{mg} / \mathrm{L}$ dan tinggi apabila $>6 \mathrm{mg} / \mathrm{L}$.

Data-data yang sudah diperoleh kemudian dianalisis menggunakan program statistik. Analisis univariat dilakukan untuk mendeskripsikan karakteristik subjek, kategori sindrom metabolik, aktivitas fisik, kejadian HTW dan kadar CRP. Data tersebut di uji kenormalannya dengan menggunakan uji Saphiro-Wilk. Uji hubungan Pearson dan Spearman dilakukan untuk menguji hubungan aktivitas fisik dengan faktor risiko sindrom metabolik serta hubungan aktivitas fisik dengan kadar CRP. Untuk mengetahui faktor risiko aktivitas fisik terhadap kadar CRP dan kejadian
HTW terhadap sindrom metabolik dan kadar CRP dengan cara menghitung nilai Risk Ratio Prevalent (RP).

\section{HASIL PENELITIAN \\ Karakteristik Umum Subyek Penelitian}

Hasil pemeriksaan status gizi ditemukan bahwa pada SMAN 2 Semarang terdapat 9,58\% siswa mengalami overweight, $7,9 \%$ siswa mengalami obesitas dan 7,3\% siswa mengalami obesitas sentral dan besar kejadian sindrom metabolik sebesar 15,2\%.

\section{Kejadian Sindrom Metabolik}

Penentuan sindrom metabolik pada remaja obesitas berdasarkan pengukuran kadar trigliserida, gula darah puasa (GDP) dan HDL serta pengukuran tekanan darah.

Tabel 1. Status Gizi dan Komponen Sindrom Metabolik pada Subyek

\begin{tabular}{|c|c|c|}
\hline Variabel & $\begin{array}{c}\text { Kelompok Sindrom } \\
\text { Metabolik }\end{array}$ & $\begin{array}{c}\text { Kelompok Pra- } \\
\text { Sindrom Metabolik }\end{array}$ \\
\hline \multicolumn{3}{|l|}{ Total } \\
\hline Usia (tahun) & $16,5(15-17)$ & $16(15-17)$ \\
\hline IMT $\left(\mathrm{kg} / \mathrm{m}^{2}\right)$ & $32,5(29,6-45,6)$ & $30,3(25,9-43,3)$ \\
\hline Lingkar Pinggang $(\mathrm{cm})$ & $105(97,5-120,3)$ & $93,5(87-134)$ \\
\hline TD Sistol $(\mathrm{mmHg})$ & $130(120-140)$ & $110(100-140)$ \\
\hline TD Diastol (mmHg) & $70(70-80)$ & $70(70-80)$ \\
\hline Trigliserida (mg/Dl) & $119(72-181)$ & $72(52-130)$ \\
\hline Kolestrol HDL (mg/Dl) & $32,5(30-48)$ & $42(30-56)$ \\
\hline GDP & $79,9 \pm 10,9$ & $82,2 \pm 6,2$ \\
\hline \multicolumn{3}{|l|}{ Laki-Laki } \\
\hline Usia (tahun) & $16,5(15-17)$ & $16(15-17)$ \\
\hline IMT $\left(\mathrm{kg} / \mathrm{m}^{2}\right)$ & $32,6(29,6-45,6)$ & $30,3(25,9-43,3)$ \\
\hline Lingkar Pinggang $(\mathrm{cm})$ & $105,9 \pm 8,1$ & $101,4 \pm 10,3$ \\
\hline TD Sistol (mmHg) & $130(120-140)$ & $120(100-140)$ \\
\hline TD Diastol (mmHg) & $70(70-80)$ & $70(70-80)$ \\
\hline Trigliserida (mg/Dl) & $117,2 \pm 32,5$ & $76,5 \pm 15,2$ \\
\hline Kolestrol HDL (mg/Dl) & $32,5(30-48)$ & $42(30-56)$ \\
\hline GDP & $79,9 \pm 10,9$ & $83,6 \pm 5,6$ \\
\hline \multicolumn{3}{|l|}{ Perempuan } \\
\hline Usia (tahun) & - & $16(15-17)$ \\
\hline IMT $\left(\mathrm{kg} / \mathrm{m}^{2}\right)$ & - & $31,4 \pm 2,8$ \\
\hline Lingkar Pinggang $(\mathrm{cm})$ & - & $90(87-114,4)$ \\
\hline TD Sistol (mmHg) & - & $110(100-120)$ \\
\hline TD Diastol (mmHg) & - & $70(70-80)$ \\
\hline Trigliserida (mg/Dl) & - & $51(56-135)$ \\
\hline Kolestrol HDL (mg/Dl) & - & $44,1 \pm 6,1$ \\
\hline GDP & - & $81 \pm 6,6$ \\
\hline
\end{tabular}

IMT Indeks Massa Tubuh, LP Lingkar Pinggang, TDS Tekanan Darah Sistol, TDD Tekanan Darah Diastol, GDP Gula Darah Puasa, $T G$ Trigliserida, HDL High Density Lipoprotein.

Tabel 1 menunjukkan status gizi dan komponen sindrom metabolik pada kelompok sindrom metabolik dan pra-sindrom metabolik. Dapat diketahui juga bahwa subyek perempuan tidak ada yang mengalami sindrom metabolik.
Hasil pengukuran antropometri dan komponen sindrom metabolik menunjukkan adanya perbedaan median dan mean pada dua kelompok subyek. Pada kelompok sindrom metabolik, median usia, IMT, lingkar pinggang, tekanan darah dan trigliserida lebih tinggi nilainya 
dibandingkan dengan kelompok pra-sindrom metabolik sedangkan median untuk komponen HDL pada kelompok sindrom metabolik lebih rendah dibandingkan kelompok pra-sindrom metabolik. Sementara itu nilai median tekanan diastolik pada kedua kelompok memiliki besar yang sama dan nilai rerata GDP yang normal pada kelompok sindrom metabolik maupun pra-sindrom metabolik

Pada kelompok subyek laki-laki sindrom metabolik, nilai median usia, IMT dan tekanan darah lebih tinggi dibandingkan kelompok subyek laki-laki pra-sindrom metabolik. Sementara itu nilai median kadar HDL pada kelompok laki-laki sindrom metabolik lebih rendah dibandingkan kelompok pra-sindrom metabolik. Terdapat perbedaan rerata trigliserida dan lingkar pinggang antara kelompok laki-laki sindrom metabolik dan pra-sindrom metabolik. Nilai rerata pada kelompok laki-laki sindrom metabolik lebih tinggi daripada kelompok laki-laki pra-sindrom metabolik.

Tabel 2. Frekuensi Faktor Risiko Sindrom Metabolik

\begin{tabular}{|c|c|c|c|c|}
\hline \multirow{2}{*}{ Komponen } & \multicolumn{2}{|c|}{$\begin{array}{c}\text { Sindrom } \\
\text { Metabolik }(n=10) \\
\end{array}$} & \multicolumn{2}{|c|}{$\begin{array}{c}\text { Pra Sindrom } \\
\text { Metabolik }(n=37)\end{array}$} \\
\hline & & & & \\
\hline LP (obesitas sentral) & 10 & $100 \%$ & 37 & $100 \%$ \\
\hline $\mathrm{TDS} \geq 122 \mathrm{mmHg}$ & 8 & $80 \%$ & 2 & $5,4 \%$ \\
\hline $\mathrm{TDD} \geq 77 \mathrm{mmHg}$ & 4 & $40 \%$ & 1 & $2,7 \%$ \\
\hline $\mathrm{GDP} \geq 110 \mathrm{mg} / \mathrm{Dl}$ & - & - & - & - \\
\hline Trigliserida $\geq 110 \mathrm{mg} / \mathrm{dL}$ & 6 & $60 \%$ & 3 & $8,1 \%$ \\
\hline $\mathrm{HDL}<40 \mathrm{mg} / \mathrm{dL}$ & 9 & $90 \%$ & 13 & $35,1 \%$ \\
\hline \multicolumn{5}{|l|}{ Laki-laki } \\
\hline Obesitas sentral $(\mathrm{LP}>93)$ & 10 & $100 \%$ & 18 & $100 \%$ \\
\hline $\mathrm{TDS} \geq 122 \mathrm{mmHg}$ & 8 & $80 \%$ & 2 & $11,1 \%$ \\
\hline $\mathrm{TDD} \geq 77 \mathrm{mmHg}$ & 4 & $40 \%$ & 1 & $5,6 \%$ \\
\hline $\mathrm{GDP} \geq 100 \mathrm{mg} / \mathrm{dL}$ & - & - & - & - \\
\hline Trigliserida $\geq 110 \mathrm{mg} / \mathrm{dL}$ & 6 & $60 \%$ & - & - \\
\hline $\mathrm{HDL}<40 \mathrm{mg} / \mathrm{dL}$ & 9 & $90 \%$ & 9 & $50 \%$ \\
\hline \multicolumn{5}{|l|}{ Perempuan } \\
\hline Obesitas sentral $(\mathrm{LP}>87)$ & - & - & 19 & $100 \%$ \\
\hline $\mathrm{TDS} \geq 122 \mathrm{mmHg}$ & - & - & - & - \\
\hline $\mathrm{TDD} \geq 77 \mathrm{mmHg}$ & - & - & - & - \\
\hline $\mathrm{GDP} \geq 110 \mathrm{mg} / \mathrm{dL}$ & - & - & - & - \\
\hline Trigliserida $\geq 110 \mathrm{mg} / \mathrm{dL}$ & - & - & 3 & $15,8 \%$ \\
\hline $\mathrm{HDL}<40 \mathrm{mg} / \mathrm{dL}$ & - & - & 4 & $21,1 \%$ \\
\hline
\end{tabular}

Catatan : IMT=Indeks Massa Tubuh, LP=Lingkar Pinggang, TDS=Tekanan Darah Sistol, TDD=Tekanan Darah Diastol, GDP=Gula Darah Puasa, TG=Trigliserida, HDL=High Density Lipoprotein.

Tabel 2 menunjukkan sebaran faktor risiko sindrom metabolik pada subjek yang mengalami sindrom metabolik dan pra-sindrom metabolik. Faktor risiko yang paling banyak terjadi adalah kadar HDL rendah dan tidak ada subyek yang memiliki faktor risiko kenaikan nilai GDP. Selain itu berdasarkan jenis kelamin, tidak semua kelompok subyek mengalami sindrom metabolik. Hanya kelompok subyek laki-laki saja yang mengalami sindrom metabolik sedangkan pada kelompok subyek perempuan dalam kondisi prasindrom metabolik.

\section{Aktivitas Fisik}

Tabel 3. Nilai Mean dan Standar Deviasi Aktivitas Fisik dan CRP pada Subyek

\begin{tabular}{cccl}
\hline Variabel & Kadar CRP Tinggi & Kadar CRP Normal & P \\
\hline Aktivitas Fisik (METs) & $1618 \pm 485$ & $2098 \pm 448$ & 0,004 \\
\hline
\end{tabular}

Berdasarkan tabel 3, terlihat bahwa rendah memiliki besar aktivitas fisik yang berbeda kelompok subyek kadar CRP tinggi dan kadar CRP $\quad(\mathrm{p}<0.05)$. 
Tabel 4. Hubungan Aktivitas Fisik dengan Faktor Risiko Sindrom Metabolik dan CRP

\begin{tabular}{lcc}
\hline \multirow{2}{*}{ Variabel } & \multicolumn{2}{c}{ Aktivitas Fisik } \\
\cline { 2 - 3 } & $\mathbf{R}$ & $\boldsymbol{P}$ \\
\hline IMT $\left(\mathrm{kg} / \mathrm{m}^{2}\right)$ & -0.202 & .224 \\
Lingkar Pinggang (cm) & -0.050 & .768 \\
TD Sistolik (mmHg) & -0.080 & .633 \\
TD Diastolik (mmHg) & 0.126 & .451 \\
GDP (mg/dL) & -0.044 & .793 \\
Trigliserida (mg/dL) & -0.093 & .578 \\
Kolesterol HDL (mg/dL) & 0.009 & .955 \\
CRP & -0.517 & .001 \\
\hline
\end{tabular}

*korelasi signifikan pada p: 0,01

Tabel 4 menunjukkan bahwa tidak terdapat sindrom metabolik namun terdapat hubungan hubungan antara aktivitas dan faktor risiko antara Aktivitas fisik dan CRP.

Tabel 5. Aktivitas Fisik sebagai faktor risiko peningkatan kadar CRP.

\begin{tabular}{|c|c|c|c|c|c|}
\hline & \multicolumn{4}{|c|}{ Kadar CRP } & \multirow{3}{*}{$\mathbf{R P}$} \\
\hline & \multicolumn{2}{|c|}{ Tinggi } & \multicolumn{2}{|l|}{ Normal } & \\
\hline & $\mathrm{N}$ & $\%$ & $\mathrm{~N}$ & $\%$ & \\
\hline \multicolumn{6}{|c|}{ Aktivitas Fisik } \\
\hline Sedang & 12 & 92,3 & 22 & 88 & \multirow{2}{*}{1,12} \\
\hline Tinggi & 1 & 7,7 & 3 & 12 & \\
\hline
\end{tabular}

Tabel 5 menunjukkan bahwa Inaktivitas Fisik Kategori C-Reactive Protein sedang merupakan faktor risiko terhadap peningkatan kadar CRP.

Tabel 6. Kadar CRP berdasarkan Jenis Kelamin dan Usia pada Subyek

\begin{tabular}{ccccc}
\hline Karakteristik & $\begin{array}{c}\text { Kadar CRP Tinggi } \\
(\mathbf{n = 1 3})\end{array}$ & $\begin{array}{c}\text { Kadar CRP Normal } \\
(\mathbf{n = 2 5})\end{array}$ \\
\hline Jenis kelamin & & & & \\
$\quad$ Laki-laki & 6 & $46,2 \%$ & 18 & $72 \%$ \\
$\quad$ Perempuan & 7 & $53,8 \%$ & 7 & $28 \%$ \\
Usia & & & & \\
15 tahun & 6 & $46,2 \%$ & 6 & $24 \%$ \\
16 tahun & 5 & $38,5 \%$ & 11 & $44 \%$ \\
17 tahun & 2 & $15,4 \%$ & 8 & $32 \%$ \\
\hline
\end{tabular}

Tabel 6 menunjukkan peningkatan CRP terjadi pada seluruh kelompok jenis kelamin dan usia. Kategori CRP tinggi terbanyak ada pada subyek perempuan.

\section{Kejadian Hypertriglyseridemic-Waist Phenotype}

$($ HTW $)$

Kejadian HTW terdiri dari 2 komponen, yaitu besar lingkar pinggang di atas $90 \mathrm{~cm}$ dan kadar trigiliserida di atas $100 \mathrm{mg} / \mathrm{dL}$. Berdasarkan komponen tersebut, kejadian HTW dapat ditunjukkan melalui tabel 7.

Tabel 7. Kejadian Hypetrigliseridemic-Waist (HTW) Phenotype

\begin{tabular}{lccccc}
\hline \multirow{2}{*}{ Kejadian } & \multicolumn{2}{c}{ Laki-laki } & \multicolumn{2}{c}{ Perempuan } & Total \\
\cline { 2 - 6 } & $\mathrm{N}$ & $\%$ & $\mathrm{~N}$ & $\%$ & $\%$ \\
\hline HTW & 8 & 21,1 & 3 & 7,9 & 28,9 \\
Non-HTW & 16 & 42,1 & 11 & 28,9 & 71,1 \\
Total & 24 & 63,2 & 14 & 36,8 & 100 \\
\hline
\end{tabular}

Tabel 7 menunjukkan kejadian HTW terbanyak ada pada subyek laki-laki. 
Tabel 8 Kejadian HTW sebagai faktor risiko kejadian sindrom metabolik

\begin{tabular}{cccccc}
\hline & \multicolumn{2}{c}{ Sindrom Metabolik } & \multicolumn{2}{c}{$\begin{array}{c}\text { Pra-Sindrom } \\
\text { Metabolik }\end{array}$} & \multirow{2}{*}{ RP } \\
\cline { 2 - 4 } & $\mathrm{N}$ & $\%$ & $\mathrm{~N}$ & $\%$ & \\
\hline $\begin{array}{c}\text { Kategori HTW } \\
\text { Kejadian HTW }\end{array}$ & 6 & $60.0 \%$ & 5 & $17,9 \%$ & \multirow{2}{*}{3,85} \\
\cline { 1 - 4 } Non-HTW & 4 & $40,0 \%$ & 23 & $82.1 \%$ & \\
\hline
\end{tabular}

Tabel 8 menunjukkan bahwa kejadian HTW $(\mathrm{RP}=$ $3,85)$ merupakan faktor risiko yang menyebabkan terjadinya sindrom metabolik.

Tabel 9 Kejadian HTW sebagai faktor risiko perubahan status kadar CRP

\begin{tabular}{|c|c|c|c|c|c|}
\hline & \multicolumn{4}{|c|}{ Kadar CRP } & \multirow{3}{*}{$\mathbf{R P}$} \\
\hline & \multicolumn{2}{|c|}{ Tinggi } & \multicolumn{2}{|c|}{ Normal } & \\
\hline & $\mathrm{N}$ & $\%$ & $\mathrm{~N}$ & $\%$ & \\
\hline \multicolumn{6}{|l|}{ Kejadian HTW } \\
\hline Kejadian HTW & 2 & $40,0 \%$ & 11 & $84,6 \%$ & \multirow{2}{*}{0.45} \\
\hline NoN-HTW & 9 & $36,0 \%$ & 16 & $64 \%$ & \\
\hline
\end{tabular}

Tabel 9 menunjukkan bahwa HTW tidak terbukti sebagai faktor risiko peningkatan CRP.

\section{PEMBAHASAN}

\section{Karakteristik Umum Subyek Penelitian}

Angka kejadian obesitas di SMAN 2 semarang sebesar 7,9\%, lebih besar jika dibandingkan dengan angka kejadian obesitas berdasarkan hasil Riskedas tahun 2013. Peningkatan angka kejadian tersebut menandakan bahwa masalah obesitas semakin meningkat. Penentuan sindrom metabolik berdasarkan NCEPATP III didapatkan kejadian sindrom metabolik di SMAN 2 Semarang sebesar 15,2 \%. Tingkat prevalensi ini lebih rendah jumlahnya jika dibandingkan dengan penelitian hasil penelitian pada tahun 2009 pada remaja obesitas di Semarang yaitu sebesar $31,64 \%$. $^{3,11}$

\section{Kejadian Sindrom Metabolik}

Pada penelitian ini ditemukan kejadian sindrom metabolik hanya terjadi pada subyek lakilaki. Pada subyek perempuan hanya ditemui kejadian pra-sindrom metabolik. Hasil penelitian ini sejalan dengan penelitian yang dilakukan pada kelompok usia 10-19 tahun di Iran yang prevalensi sindrom metabolik pada laki-laki sebesar $11 \%$ sedangkan pada wanita sebesar 7\%. ${ }^{19}$ Lingkar pinggang yang semakin besar dapat meningkatkan risiko terjadinya sindrom metabolik. ${ }^{20}$ Pada penelitian ini rerata lingkar pinggang pada subyek laki-laki lebih besar daripada subyek perempuan oleh karena itu kejadian sindrom metabolik banyak terjadi pada subyek laki-laki. Kejadian sindrom metabolik dapat dipengaruhi oleh jenis kelamin. Keberadaan hormon estrogen pada wanita dapat meningkatkan aktivasi reseptor HDL yang dapat mempertahankan kadar HDL tetap tinggi. ${ }^{21}$ Selain itu hormon estrogen dapat mengurangi lipogenesis, mengurangi sekresi enzim lipoprotein lipase yang dapat meningkatkan katalisasi trigliserida menjadi asam lemak bebas. ${ }^{22}$ Apabila asam lemak bebas meningkat maka jumlah Very Low Density Lipoprotein (VLDL) akan meningkat. Peningkatan VLDL akan menyebabkan peningkatan LDL dan menurunkan kadar HDL. ${ }^{23}$ Keberadaan estrogen juga dapat mempengaruhi kadar gula darah. Reseptor esterogen dapat meningkatkan kerja sel p-pankreas sehingga produksi dan sensitivitas insulin meningkat. ${ }^{24}$ Kejadian sindrom metabolik juga dapat dipengaruhi oleh umur. Penelitian di Amerika Serikat menunjukkan adanya peningkatan kejadian sindrom metabolik pada perempuan dengan kelompok usia lebih tua. ${ }^{25}$ Pada keadaan menopause, estrogen dalam tubuh menurun yang dapat meningkatkan faktor risiko terjadinya sindrom metabolik ${ }^{26}$

Pada penelitian ini, urutan faktor risiko yang paling banyak terjadi adalah obesitas sentral (90\%), kadar kolestrol HDL rendah (90\%), hipertensi (80\%), dan hipertrigliserida (60\%). Pada penelitian ini, lingkar pinggang berjumlah $100 \%$ sebab skrining awal pencarian subyek penelitian menggunakan lingkar pinggang di atas persentil 90. Hasil penelitian ini sejalan dengan penelitian yang dilakukan pada remaja di Brazil dengan faktor risiko terbesar sindrom metabolik adalah 
lingkar pinggang $(54,5 \%)$, diikuti penurunan kadar HDL $(37,7 \%)$, tekanan darah $(18,2 \%)$, trigliserida (13\%), dan GDP (1,3\%). Kadar GDP normal menunjukkan bahwa hiperglikemi merupakan kejadian paling akhir yang muncul pada sindrom metabolik remaja. Kadar GDP yang normal menunjukkan bahwa hormon insulin masih berfungsi normal dan hal ini juga menunjukkan belum terjadi kelainan metabolisme karbohidrat. ${ }^{27}$

\section{Aktivitas Fisik}

Pada penelitian ini secara statistik tidak menunjukkan adanya hubungan antara aktivitas fisik dengan faktor risiko sindrom metabolik, tetapi uji statistik menunjukkan arah korelasi negatif antara aktivitas fisik dengan faktor risiko sindrom metabolik. Hal ini menunjukkan bahwa aktivitas fisik berbanding terbalik dengan faktor risiko sindrom metabolik. ${ }^{28}$

Aktivitas fisik yang tinggi dapat mengurangi masa lemak. Masa lemak yang berkurang tersebut juga turut mengurangi pelepasan adipokin. Pelepasan adipokin yang dilepaskan seperti angiotensin, Tumor Necrosis Factor (TNF-a), resitin, dan leptin. ${ }^{29}$ Penurunan jumlah adipokin seperti TNF-a dapat berdampak pada sensitivitas insulin. ${ }^{30}$ Apabila TNF-a menurun, tirosin kinase akan bekerja secara optimal sehingga aktivitas Glucose Transporter (GLUT)-4 dalam mengambil glukosa darah mengalami peningkatan. Akibatnya sensitivitas insulin semakin meningkat dan kadar gula darah dapat bertahan dalam keadaan normal. Adipokin seperti leptin juga memiliki pengaruh terhadap penebalan karotid intima. ${ }^{31}$ Penebalan karotid intima akan memicu disfungsi endotelial dan perubahan struktur pembuluh darah. Disfungsi endotelial dapat menyebabkan menurunnya jumlah nitrit oksida. Nitrit oksida dalam jumlah yang rendah dapat meningkatkan tekanan darah. ${ }^{32}$ Selain itu TNF-a juga berperan dalam aktivasi angiotensin II. ${ }^{33}$ Peningkatan angiotensin II berperan dalam peningkatan tekanan darah. Aktivitas fisik juga memiliki arah korelasi negatif pada kadar trigliserida namun memiliki arah korelasi positif pada kadar HDL. ${ }^{34}$ Peningkatan aktivitas fisik dapat meningkatkan penggunaan trigliserol sebagai sumber energi. Pemecahan trigliserol dalam jumlah tinggi akan berpengaruh terhadap penurunan kadar trigliserida. Kadar trigliserida yang rendah dalam tubuh akan mempengaruhi metabolisme lipid tubuh sehingga dapat menyebabkan kadar HDL meningkat. ${ }^{35}$

Pada penelitian ini aktivitas fisik memiliki hubungan terbalik dengan kadar CRP. Hasil ini sejalan dengan penelitian pada tahun 2009 yaitu aktivitas fisik yang tinggi memiliki hubungan terhadap kadar CRP yang rendah. ${ }^{36}$ Mekanisme mengenai hubungan aktivitas fisik masih belum dapat diketahui dengan jelas. ${ }^{37}$ Diduga, penurunan IL-6 yang menyebabkan CRP ikut menurun. ${ }^{38}$ Dugaan lain hubungan CRP dengan aktivitas fisik disebabkan oleh dilepaskannya senyawa antiinflamatori ketika berolahraga sehingga kadar CRP mengalami penurunan. ${ }^{39}$

\section{Kategori C-Reactive Protein}

Peningkatan CRP terjadi pada seluruh kelompok jenis kelamin. Kategori CRP tinggi lebih banyak terjadi pada perempuan. Penelitian tahun 2006 menyebutkan bahwa perempuan dengan kadar CRP tinggi jumlahnya lebih banyak daripada laki-laki. ${ }^{40} \mathrm{Hal}$ ini dapat dijelaskan berdasarkan hormon endogen yang dimiliki kedua subyek. Pada laki-laki terdapat hormon testosteron yang dapat menginhibisi adiposit untuk melepaskan adiponektin. ${ }^{41}$ Inhibisi adiponektin ini dapat mengurangi jumlah dilepaskannya interleukin (IL)$6 .{ }^{42}$ Banyaknya CRP yang dikeluarkan oleh hepatosit tergantung pada IL-6. Apabila IL-6 keluar dalam jumlah sedikit maka jumlah CRP yang dilepaskan oleh hepatosit juga sedikit. Pada perempuan terdapat hormon esterogen yang bersifat meningkatkan kadar CRP. ${ }^{43}$

\section{Kejadian Hypertrigliseridemic-Waist (HTW) Phenotype}

Pada penelitian ini jumlah subyek laki-laki yang mengalami HTW sebesar $21,1 \%$ dan perempuan sebesar $7,9 \%$. Hasil ini sesuai dengan penelitian di Brazil pada tahun 2012 yang menyebutkan kejadian HTW lebih banyak terjadi di laki-laki $(7,9 \%)$ daripada perempuan $(6,8 \%){ }^{44}$ Penelitian ini menunjukkan bahwa HTW merupakan faktor risiko terjadinya sindrom metabolik, hipokolestrol HDL, peningkatan tekanan darah sistolik, dan peningkatan tekanan darah diastolik. Sedangkan pada status proinflamatori hanya memiliki besar risiko 0,45 . HTW diketahui merupakan faktor risiko terjadinya hipokolestrolemia HDL. ${ }^{45}$ Selain itu HTW juga merupakan faktor terjadinya peningkatan CRP. Sedangkan HTW sebagai peningkatan tekanan darah masih sulit dijumpai penelitiannya. ${ }^{46}$

HTW sebagai faktor risiko terjadinya sindrom metabolik dapat dijelaskan dari kenaikan lingkar pinggang. ${ }^{47}$ Kenaikan lingkar pinggang memiliki kaitan yang erat dengan kenaikan trigliserida. Kenaikan trigliserida juga dapat meningkatkan risiko terjadinya kenaikan CRP. Diketahui bahwa terdapat hubungan yang erat antara kadar nilai trigliserida dengan jaringan adiposa yang terdapat di viseral. ${ }^{48}$ Jaringan lemak 
viseral merupakan jaringan lemak yang aktif melepaskan adiponekin. Adiponekin tersebut akan meningkatkan asam lemak dan lipolisis adiposa. Hasil dari lipolisis adiposa ada Non-Esterified Fatty Acids (NEFA) yang akan diantarkan menuju hepar. ${ }^{49}$ Peningkatan lipolisis adiposa tentu akan meningkatkan jumlah NEFA. Peningkatan NEFA ini berdampak pada peningkatan trigliserida, sintesis VLDL dan menurunkan metabolisme lipoprotein. Akibatnya kadar HDL akan menurun dan LDL akan meningkat. Ketika LDL terdapat dalam jumlah banyak dan jumlah antioksidan terbatas maka akan memicu terjadinya sel busa sehingga menimbulkan plak. Setelah itu CRP dalam bentuk pentamer akan dikeluarkan sebagai bentuk respon terjadinya inflamasi. Akibatnya, kadar NO akan menurun yang akan membuat CRP menghambat angiogenesis dan merangsang apoptosis sel endotel. Hal ini lah yang menyebabkan peningkatan risiko hipertensi. ${ }^{50}$

\section{SIMPULAN}

Dari penelitian ini dapat diketahui bahwa terdapat prevalensi obesitas sebesar $7,9 \%$ di SMAN 2 Semarang. Prevalensi ini lebih tinggi jika dibandingkan dengan angka prevalensi obesitas Riskesdas 2013. Pada penelitian ini juga didapati remaja yang mengalami obesitas sentral telah mengalami sindrom metabolik. Selain itu penelitian ini juga membuktikan telah terjadinya reaksi inflamasi berupa peningkatan kadar $C$ Reactive Protein $(C R P)$ pada remaja obesitas sentral yang mengalami sindrom metabolik maupun pra-sindrom metabolik. Dari penelitian ini juga diketahui bahwa inaktivitas fisik merupakan faktor risiko terjadinya peningkatan kadar CRP dan HTW merupakan faktor risiko terjadinya sindrom metabolik namun tidak terbukti terhadap peningkatan kadar CRP.

\section{SARAN}

Perlunya pengukuran tekanan darah secara berulang dan dalam kondisi kondusif.

\section{DAFTAR PUSTAKA}

1. Badan Litbang Kesehatan Departemen Kesehatan RI. Laporan Hasil Riset Kesehatan Dasar (Riskesdas) Nasional. Jakarta. 2010.

2. Badan Litbang Kesehatan Departemen Kesehatan RI. Laporan Hasil Riset Kesehatan Dasar (Riskesdas) Nasional. Jakarta. 2013.

3. Llyod, S. C Langley-Evans, McMullen. Childhood obesity and risk of the adult metabolic syndrome: a systematic review. International Journal of Obesity. 2012.
4. Jean-Pierre Després. Body Fat Distribution and Risk of Cardiovascular Disease: An Update. Circulation. 2012;126:1301-1313. American Heart Association ISSN: 1524-4539

5. Mexitalia M, Utari Agustini, Sakundarno M, Yamauchi Taro, Subagio Hertanto Wahyu,Soemantri Agustinus. Sindrom Metabolik pada Remaja Obesitas. Media Medika Indonesia. Volume 43, Nomor 6, Tahun 2009.

6. Vandewater Elizabeth, Shim Mi-suk, Caplovitz G. Allison. Linking obesity and activity level with children's television and video game use. Journal of Adolescence 27 (2004) 71-85

7. Corneel Vandalenotte, Takemi Sugiyama, Paul Gardiner, Neville Owen. Association of LeisureTime Internet and Computer Use with Overweight and Obesity, Physical Activity and Sendentary Behaviors: Cross-Sectional Study. J Med Internet Rses. Juli, 2009

8. Transportation Department North Central Texas Council of Goverment. Obesity, Transportation and Land Use.

9. Joseph A Hournard, Charled J Tanner, Cris A Slentz, Brian D Duscha. Effect of volume and intensity of excercise training on insulin sensitivity. Journal of Applied Physiology.

10. Frank W Booth, Christian K. Roberts. Lack of Excercise Is a Major Cause of Chronic Diseases. American Physiological Society. 2012

11. Benoit J. Arsenault, Isabelle Lemieux, Jean-Pierre Després, Nicholas J. Wareham MBBS, John J.P. Kastelein, Kay-Tee Khaw MBBChir, et.al. The hypertriglyceridemic-waist phenotype and the risk of coronary artery disease: results from the EPICNorfolk Prospective Population Study

12. The IDF Consensus worldwide definition of the metabolic syndromeSir George Alberti, London, UK Paul Zimmet, Melbourne, AustraliaJonathan Shaw, Melbourne, Australia Scott M. Grundy

13. Blackburn P, Lemieux I, Lamarche B, Bergeron J, Perron P, Tremblay G, et al. Hypertriglyceridemic waist: a simple clinical phenotype associated with coronary artery disease in women. Metabolism. 2012;61:56-64

14. Gomez-Huelgas R, Bernal-López MR, Villalobos A, Mancera-Romero J, Baca-Osorio AJ, Jansen S, et al. Hypertriglyceridemicwaist: an alternative to the metabolic syndrome? Results of the IMAP Study (multidisciplinary intervention

15. Sam S, Haffner S, Davidson MH, D'Agostino RB Sr, Feinstein S, Kondos G, et al. Hypertriglyceridemic waist phenotype predicts increased visceral fat in subjects with type 2 diabetes. Diabetes Care. 2009;32:1916-20

16. Haffner SM (2006) The metabolic syndrome: inflammation, diabetes mellitus, and cardiovascular disease. Am J Cardiol 97: 3A-11A.

17. K Tamakoshi, H Yatsuya, T Kondo, Y Hori, M Ishikawa, H Zhang, C Murata, R Otsuka, S Zhu and $\mathrm{H}$ Toyoshima. The metabolic syndrome is 
associated with elevated circulating C-reactive protein in healthy reference range, a systemic lowgrade inflammatory state. International Journal of Obesity (2003) 27, 443-449

18. Earl S. Ford, Umed A. Ajani. Ali. H. Mokdad. The metabolic syndrome and concentration in of $\mathrm{C}$ Reactive Protein Among Youth US

19. Homeira Rashidi, Seyed Peyman Payami, Seyed Mahmoud Latifi, Majid Karandish, Armaghan Moravej Aleali, Majid Aminzadeh, et. al. Prevalence of metabolic syndrome and its correlated factors among children and adolescents of Ahvaz aged 10 - 19 Journal of Diabetes \& Metabolic Disorders 2014, 13:53 BioMed Central

20. Tan CE, Ma S, Wai D, Chew SK, Tai ES. Can we apply the National Cholesterol Education Program Adult Treatment Panel definition of the metabolic syndrome to Asians? Diabetes Care 2004;27:11821186.

21. Peter T. Katzmaryk. Ian Janseen, Robert Ross. Timothy S. Church, Steven N. Blair. The importance of Waist Circumference in the definition of Metabolic Syndrome. Diabetes Care 29:404-409, 2006.

22. Estrogen activates the high-density lipoprotein receptor gene via binding to estrogen response elements and interaction with sterol regulatory element binding protein-1A. Lopez $\mathrm{D}^{1}$, Sanchez MD, Shea-Eaton W, McLean Endocrinology. 2002 Jun;143(6):2155-68.

23. Petrasek K. Vondra. M. Duskova L, Starka. Metabolic Profile and Sex Hormone Binding Globulin (SHBG) in Different Reproductive Phase of Chezh Women and Their Relation to Weight, Body Compotion and Fat Distribution Physiological Research. ISSN 0862-8408. 2009. Institute of Physiology. Academy of Sciences of the Czech Republic, Prague. Czeh Republic

24. Alonso-Magdalena P, Ropero AB, Carrera MP, Cederroth CR, Baquie M, Gauthier BR, Nef S, Stefani E \& Nadal A 2008 Pancreatic insulin contentregulation by the estrogen receptor ER $\begin{array}{llll}\text { alpha. PLoS ONE } & 3 & \text { e2069. }\end{array}$ (doi:10.1371/journal.pone.0002069)

25. Homma $H$, Kurachi $H$, Nishio $Y$, Takeda $T$, Yamamoto T, Adachi K, Morishige K, Ohmichi M, Matsuzawa Y \& Murata Y 2000. Estrogen suppresses transcription of lipoprotein lipase gene. Existence of a unique estrogen response element on the lipoprotein lipase promoter. Journal of Biological Chemistry 275 11404-11411. (doi:10.1074/jbc.275.15.11404)

26. Jennifer L. Kuk. Chris I. Ardern. Age and Sex Differences in the Clusteringof Metabolic Syndrome Factors. Diabetes Care, Volume 33. November 2011

27. Rizzo AC, Goldberg TB, Silva CC, Kurokawa CS, Nunes HR, Corrente JE.. Metabolic Syndrome Risk Factors in Overweight, Obes, and Extremely Obese
Brazillian Adolescent. Nutrition Journal. 2013;1475-2891

28. Blair SN. Evidence for success of exercise in weight loss and control. Ann Intern Med. 1993;119:702-706

29. Yung LM, Laher I, Yao X, et al. Exercise, vascular wall and cardiovascular diseases: an update (part 2). Sports Med. 2009;39:45---63.

30. Mayer-Davis EJ, D'Agostino R Jr, Karter AJ, et al. Intensity and amount of physical activity in relation to insulin sensitivity: the Insulin Resistance Atherosclerosi.Study. JAMA. 1998;279:669-674.

31. Ciccone M, Vettor R, Pannacciulli N, Minenna A, Bellacicco M, Rizzon P, Giorgino R \& De Pergola $G$ (2001). Plasma leptin is independently associated with the intima-media thickness of the common carotid artery. Int J Obes Relat MetabDisord 25, 805-810.

32. Zera $\mathrm{T}$, Ufnal $\mathrm{M} \&$ Szczepanska-Sadowska $\mathrm{E}$ (2008). Central TNF- $\alpha$ elevates blood pressure and sensitizes to central pressor action of angiotensin II in the infarcted rats. J PhysiolPharmacol 59, 117 121.

33. John Skoumas, Christos Pitsavos, Demosthenes B Panagiotakos*,Christina Chrysohoou, Akis Zeimbekis, Ioanna Papaioannou, Physical activity, high density lipoprotein cholesterol and other lipids levels, in men and women from the ATTICA study

34. Marina Toutouza, Pavlos Toutouza and Christodoulos Stefanadis. Lipids in Health and Disease. 2003 BioMed Central

35. W.W Christie. Plasma Lipoproteins composition, structure and biochemistry, lipilibrary,org

36. Carmen R. Isasi, Richard J. Deckelbaum, Russell P. Tracy, Thomas J. Starc, Lars. Physical Fitness and C-Reactive Protein Level in Children and Young Adults: The Columbia University BioMarkers Study Pediatrics 2003;111;332

37. Julia Wärnberg1,2,3*, Karen Cunningham4, Javier Romeo1 and Ascension Marcos1

38. 3rd International Immunonutrition Workshop Session 6: Role of physical activity on immune function Physical activity, exercise and low-grade systemic inflammation. Proceedings of the Nutrition Society (2010),

39. Susan G. Lakoski, MD, MS, Mary Cushman, MD, MSc, Michael Criqui, MD, MPH, Tatjana Rundek, $\mathrm{MD}, \mathrm{PhD}$, Roger S. Blumenthal, MD, Ralph B. D'Agostino Jr, PhD, David M. Herrington, MD, MHS. Gender and C-reactive Protein: Data From the Multiethnic Study of Atherosclerosis (MESA) Cohort. Am Heart J. 2006;152(3):593-598.

40. Amit Khera, Darren K. McGuire, Sabina A. Murphy, Harold G. Stanek, Sandeep R. Das et. al Race and Gender Differences in C-Reactive Protein Levels. Journal of the American College of Cardiology Vol. 46, No. 3, 2005 ISSN 07351097/05

41. GA Laughlin, E Barrett-Connor and S MaySexspecific determinants of serum adiponectin in older 
adults: the role of endogenous sex hormones. International Journal of Obesity (2007) 31, 457465 \& 2007 Nature Publishing Group All rights reserved 0307-0565/07

42. Maria Ester P. da Conceição-Machado, Luciana R. Silva, Mônica Leila P. Santana, Elizabete J. Pinto, Rita de Cássia R. Silva, Lia Terezinha L.P. Moraes, et al. Hypertriglyceridemic waist phenotype: association with metabolic abnormalities in adolescents. J Pediatr (Rio J). 2013;89(1):56-63

43. Ahmad Esmaillzadeh, Parvin Mirmiran, and Fereidoun Azizi Clustering of metabolic abnormalities in adolescents with the hypertriglyceridemic waist phenotype. 2006 American Society for Clinical Nutrition. Am J Clin Nutr 2006;83:36 - 46.

44. Nayra Anielly, Valdinar Sousa, Ana Karina, Joao Victor, Alcioen Miranda, Natalino Salgado et.al. Hypertriglyceridemic waist and cardiometabolic risk in hypertensive Women. ://http://www.journalofoptometry.org

45. Marielle Kapaln, Shadi Hamoud, Yevgeny Tendler, Edna Meilin, Aviva Lazarovitch, Samy Nitecki. et. al. A significant correlation between C-Reactive Protein Levels in Blood Monocytes Derived Macrophages Versus Content in Carotid Atherosclerotic Lesions. Journal of Inflammation 2013; 11;7

46. Michael Miller, Neil J. Stone, Christie Ballantyne, Vera Bittner, Michael H. Criqui, Henry N. Ginsberg, Anne Carol Goldberg, William James Howard, Marc S. Jacobson, Penny M. Triglycerides and Cardiovascular Disease: A Scientific Statement From the American Heart Association Circulation. 2011;123:2292-2333; originally published online April 18, 2011.

47. Steffen U. Eisenhardt, Jonathon Habersberger, Andrew Murphy, Yung-Chih Chen, Kevin J, Constantin von zur Muhlen, Christoph E. et.al Dissociation of Pentameric to Monomeric CReactive Protein on Activated Platelets Localizes Inflammation to Atherosclerotic Plaques. 2009;105:128-137; originally published online June 11, 2009; Circ Res.

48. K Tamakoshi, H Yatsuya, T Kondo, Y Hori, M Ishikawa, H Zhang, C Murata, R Otsuka, S Zhu and $\mathrm{H}$ Toyoshima. The metabolic syndrome is associated with elevated circulating C-reactive protein in healthy reference range, a systemic lowgrade inflammatory state. International Journal of Obesity (2003) 27, 443-449

49. Sander J. Robins, Asya Lyass, Justin P. Zachariah, Joseph M. Massaro and Ramachandran S. Vasan. Insulin Resistance and the Relationship of a Dyslipidemia to Coronary Heart Disease: The Framingham Heart Study. Arterioscler Thromb Vasc Biol. 2011;31:1208-1214; originally published online February 102011

50. Hidekatsu Yanai, Yoshiharu Tomono, Kumie Ito, Nobuyuki Furutani, Hiroshi Yoshida and Norio
Tada. The underlying mechanisms for development of hypertension in the metabolic syndrome. Nutrition Journal 2008, 7:10 